\title{
A METHOD FOR EVALUATING ERGOSTEROL CONTENT IN WOOD-DECAY FUNGI
}

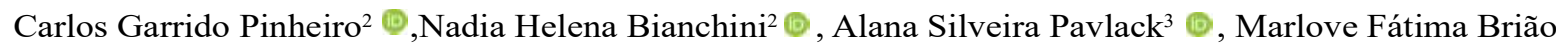
Muniz $^{4} \odot$,Victor Dos Santos Barboza ${ }^{5} \odot$, Maria Amália Pavanato ${ }^{6} \odot$, Fernando Nunes Gouveia $^{7} \odot$ and Berta Maria Heinzmann ${ }^{8 *} \cdot$

\footnotetext{
${ }^{1}$ Received on 12.10.2018 accepted for publication on 22.01.2020.

${ }^{2}$ Universidade Federal de Santa Maria, Programa de Pós-Graduação em Engenharia Florestal, Santa Maria, RS-Brasil . E-mail: < pinheiro. gcarlos@gmail.com> and <nhbianchini@gmail.com>.

${ }^{3}$ Universidade Federal de Santa Maria, Graduanda em Engenharia Florestal, Santa Maria, RS-Brasil. E-mail: <alanapavlack@hotmail. com>.

${ }^{4}$ Universidade Federal de Santa Maria, Departamento de Defesa Fitossanitária, Santa Maria, RS-Brasil. E-mail: <marlovemuniz@yahoo. com.br>.

${ }^{5}$ Universidade Federal de Santa Maria, Programa de Pós-Graduação em Farmacologia, Santa Maria, RS-Brasil. E-mail: <victorbarboza10@ gmail.com>.

${ }^{6}$ Universidade Federal de Santa Maria, Departamento de Fisiologia e Farmacologia, Santa Maria, RS-Brasil. E-mail: <amaliapavanato@ yahoo.com.br>.

${ }^{7}$ Serviço Florestal Brasileiro, Laboratório de Produtos Florestais, Brasília, DF-Brasil. E-mail: < fernando.gouveia@florestal.gov.br>.

${ }^{8}$ Universidade Federal de Santa Maria, Departamento de Farmácia Industrial, Santa Maria, RS-Brasil. E-mail: <berta.heinzmann@gmail. com>.

${ }^{*}$ Corresponding author.
}

\begin{abstract}
Ergosterol is responsible for important functions in the fungal plasma membrane. The influence of fungitoxic agents on membrane ergosterol content is one of the most important mechanisms of antifungal action and its knowledge allows the generation of products that associate active compounds of different mechanisms, consequently improving the effectiveness of wood preservatives. Therefore, this study optimized a method for quantifying ergosterol in wood-decay fungi. The white-rot species selected were Ganoderma applanatum and Trametes versicolor, while the brown-rot were Gloeophyllum trabeum and Lentinus lepideus. Mycelial discs of each species were transferred to Petri dishes containing a cellophane-covered potatodextrose-agar medium. Mycelia of each fungus were collected, weighed, and transferred to test tubes with $5 \mathrm{~mL}$ of $25 \%$ alcoholic potassium hydroxide. The tubes were vortexed for $5 \mathrm{~min}$, subjected to ultrasound for $5 \mathrm{~min}$, incubated at $85{ }^{\circ} \mathrm{C}$ for $4 \mathrm{~h}$, followed by the addition of $2 \mathrm{~mL}$ of sterile distilled water and $5 \mathrm{~mL}$ of $n$-heptane and subsequent ultrasound shaking for $2 \mathrm{~min}$. The $n$-heptane layer was analyzed by UV spectrophotometry between 230 and $300 \eta \mathrm{m}$. The blank sample only contained $n$-heptane. The mycelia wet weight of the fungi ranged from 0.061 to $0.296 \mathrm{~g}$. Ergosterol content was $0.007 \%$ for Lentinus lepideus and $0.004 \%$ for the other species. The absorbance was higher than the ones observed in the blank for all samples. The adapted method was efficient for ergosterol extraction.
\end{abstract}

Keywords: Sterol; Mycelia; Extraction.

\section{UM MÉTODO PARA AVALIAR O CONTEÚDO DE ERGOSTEROL EM FUNGOS APODRECEDORES DA MADEIRA}

RESUMO - O ergosterol é responsável por importantes funções na membrana plasmática dos fungos. A influência de agentes fungitóxicos no conteúdo de ergosterol na membrana é um dos mecanismos mais importantes de ação antifúngica e seu conhecimento permite a geração de produtos que associam compostos ativos de diferentes mecanismos, consequentemente, melhorando a eficácia dos conservantes de madeira. Portanto, este estudo otimizou um método para quantificar ergosterol em fungos apodrecedores da madeira. As espécies de podridão-branca selecionadas foram Ganoderma applanatum e Trametes versicolor, enquanto que as de podridão-parda foram Gloeophyllum trabeum e Lentinus lepideus. Discos miceliais de cada espécie foram transferidos para placas de Petri contendo meio batata-dextrose-ágar coberto por celofane. O micélio de cada fungo foi coletado, pesado e transferido para tubos de ensaio com $5 \mathrm{~mL}$ de hidróxido de potássio

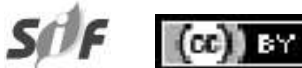

Revista Árvore 2020;44:e4410 http://dx.doi.org/10.1590/1806-908820200000010 
alcoólico 25\%. Os tubos foram agitados em vortex por 5 min, submetidos a ultrassom por 5 min, incubados a $85{ }^{\circ} \mathrm{C}$ por $4 \mathrm{~h}$, seguido da adição de $2 \mathrm{~mL}$ de água destilada estéril e $5 \mathrm{~mL}$ de $\boldsymbol{n}$-heptano e subsequente agitação em ultrassom por 2 min. A camada de n-heptano foi analisada por espectrofotometria no UV entre 230 e 300 $\eta m$. O branco continha apenas $\boldsymbol{n}$-heptano. A massa micelial úmida dos fungos variou de 0,061 a 0,296 g. $O$ teor de ergosterol foi de 0,007\% para Lentinus lepideus e 0,004\% para as demais espécies. A absorbância foi maior que a observada no branco para todas as amostras. $O$ método adaptado foi eficiente para extração de ergosterol.

Palavras-Chave: Esteroide; Micélio; Extração.

\section{INTRODUCTION}

Different biological agents can attack wood-based products, including wood-decay fungi (Stangerlin et al., 2013). These organisms can cause serious damage to wooden structures, which may result in considerable economic and resource losses (Cheng et al., 2008). These fungi belong to the class Basidiomycetes and are classified as white and brown rots (Oliveira et al., 2005). The white-rot group is characterized by the capacity to degrade lignin, hemicellulose, and cellulose, while the brown-rot fungi are characterized by the degradation of wood polysaccharides (Martínez et al., 2005).

To circumvent the losses caused by wood-decay fungi on wood products, preservatives are usually used (Mendes et al., 2014; Vivian et al., 2015). However, some preservatives have high toxicity, therefore, research is necessary to obtain alternative fungitoxic agents that are effective in combating wood rot (Brand et al., 2006; Xie et al., 2017).

Ergosterol is the major sterol in the fungal membrane (Hu et al., 2017) and responsible for important growth functions (Mota et al., 2012). Among these functions are its contribution to membrane fluidity and integrity in addition to supporting the normal operation of membrane-bound enzymes (Lupetti et al., 2002). Ergosterol is produced by wood-decay fungi, both in white-rot and brown-rot fungi (Presley and Schilling, 2017; Xie et al., 2017).

The effect of a product on ergosterol content in plasma membrane is a known mechanism of antifungal action (Tian et al., 2012; Kedia et al., 2014; Avanço et al., 2017). Determining a method for ergosterol evaluation is necessary in order to confirm the mechanism of antifungal action of antifungal agents in wood-decay fungi. Knowledge of fungitoxic compound mechanisms allows the generation of products that associate active compounds of different mechanisms that are more effective as wood preservatives.
Considering that ergosterol content in wooddecay fungi vary between white-rot and brown-rot ones (Niemenmaa et al., 2008), the possibility that the evaluation of this sterol can be used to study mechanism of antifungal action, and that the extraction methods proposed by Arthington-Skaggs et al. (1999) and Tian et al. (2012) were not effective for this group of fungi, the present study optimized a method for ergosterol evaluation in wood-rotting fungi using the white-rot fungi Ganoderma applanatum and Trametes versicolor and the brown-rot fungi Gloeophyllum trabeum and Lentinus lepideus as models.

\section{MATERIAL AND METHODS}

\subsection{Fungal growth in PDA with and without cellophane membrane}

Both the white-rot fungi ( $G$. applanatum and T. versicolor) and brown-rot fungi (G. trabeum and L. lepideus) were provided by the Forest Products Laboratory (Laboratório de Produtos Florestais) situated at Universidade de Brasília, DF, Brazil. The fungal strains were deposited at the Herbarium of the Biology Department, UFSM, Brazil. Ganoderma applanatum (SMDB 17,748), T. versicolor (SMDB 17,749), G. trabeum (SMDB 17,751), and L. lepideus (SMDB 17,750) were initially cultivated in 9-cm Petri dishes containing potato-dextrose-agar (PDA). Two treatments were used: PDA with and without a cellophane membrane (Bento et al., 2014) in order to confirm whether the membrane influences mycelial growth. Mycelial discs (11 mm of diameter) of each fungus species were transferred (in three repetitions) to the Petri dishes which were then sealed with parafilm and kept in a Biochemical Oxygen Demand (BOD) chamber at $25{ }^{\circ} \mathrm{C}( \pm 1)$ at light/dark cycle of $12 / 12 \mathrm{~h}$. The first evaluation was done on the $7^{\text {th }}$ day after the beginning of the experiment through two measurements diametrically opposite to each other. The test was considered finished when the fungal growth of each

Revista Árvore 2020;44:e4410 
dish completely covered the medium (Badawy and Abdelgaleil, 2014). Data normality and homogeneity of variances were confirmed, one-way ANOVA performed, and the averages were compared by Tukey's test using SigmaPlot 11.0 software.

\subsection{Ergosterol content analysis in the plasma membrane of the wood-decay fungi}

The white-rot fungi G. applanatum and T. versicolor and the brown-rot G. trabeum and L. lepideus were first cultivated in Petri dishes containing PDA, for fifteen days, in a BOD chamber at $25{ }^{\circ} \mathrm{C}( \pm 1)$ at a light/dark cycle of $12 / 12 \mathrm{~h}$. Then, mycelial discs (11-mm diameter) of each fungal species were transferred to Petri dishes containing cellophane membrane-covered PDA (Bento et al., 2014). Afterwards, the dishes were sealed and moved to a BOD chamber in which they remained for 5 days. All treatments were done with three repetitions.

An adaptation of the method by Arthington-Skaggs et al. (1999) and Tian et al. (2012) was developed for mycelial ergosterol extraction. After the incubation period, mycelia from each wood-decay fungus were harvested and their wet weight determined. Fungal mycelia along with $5 \mathrm{ml}$ of $25 \%$ alcoholic potassium hydroxide were transferred to test tubes and vortex mixed for $5 \mathrm{~min}$ (Velp Scientifica, Vortex Mixer, Wizard $\mathrm{X})$. The mixed samples were transferred to ultrasound (Unique Ultrasonic Clean, model Ultra Cleaner 1450A with heating) and remained there for $5 \mathrm{~min}$. After ultrasound treatment, the test tubes were incubated at $85{ }^{\circ} \mathrm{C}$ for $4 \mathrm{~h}$. Then, $2 \mathrm{ml}$ of sterile distilled water and $5 \mathrm{ml}$ of $n$-heptane were added to the test tubes, which remained in an ultrasound bath for $2 \mathrm{~min}$. The solution layers of each fungus were separated into funnels for 1 $\mathrm{h}$ at room temperature. The $n$-heptane layer of each tube was collected and analyzed by UV spectrophotometry (Biospetro sp-220) between 230 and $300 \eta \mathrm{m}$. The absorbance at $282 \mathrm{\eta m}$ characterized the presence of ergosterol in $n$-heptane layer, while the reading obtained at 230 and $282 \eta \mathrm{m}$ corresponded to the late sterol intermediate 24(28) dehydroergosterol (Tian et al., 2012). Blank samples containing only $n$-heptane were also analyzed by UV spectrophotometry at the same wavelengths.

The estimation of ergosterol amount was done based on the fungal mycelia wet weight $(\mathrm{g})$ and absorbance values obtained by considering the formulas adapted from Tian et al. (2012): \%24(28) dehydroergosterol $=(\mathrm{A} 230 / 518) /$ mycelia wet weight; \% ergosterol + $\% 24(28)$ dehydroergosterol $=(\mathrm{A} 282 / 290) /$ mycelia wet weight. For the described formulas, 290 and 518 were considered the $\mathrm{E}(\% / \mathrm{cm})$ values for crystalline ergosterol and 24(28) dehydroergosterol. Graphics and analysis were obtained using Microsoft Office Excel and SigmaPlot 11.0.

\section{RESULTS}

After 15 days, all Petri dishes containing PDA with and without cellophane membrane were completely covered by wood-decay fungi. No significant differences were found in mycelial growth in PDA among $G$. applanatum, T. versicolor, G. trabeum, and L. lepideus with and without the cellophane membrane (Table 1).

The procedure tested in this study obtained mycelial wet weights of $0.079 \pm 0.225,0.296 \pm 0.0267,0.079$ \pm 0.0225 , and $0.061 \pm 0.0044 \mathrm{~g}$ for $G$. applanatum, $T$. versicolor, G. trabeum, and $L$. lepideus, respectively (Figure 1). For the first three species, ergosterol content was $0.004 \pm 0.0005 \%$. Ergosterol content for L. lepideus was $0.007 \pm 0.0013 \%$ (Figure 1).

In order to demonstrate the efficiency of the ergosterol extraction method, the results are presented in two different manners: the percentage of ergosterol obtained for each fungus and the UV spectrophotometric profiles of this sterol for each species (Figure 2). For all samples, the absorbance values between 230 and 300 $\eta \mathrm{m}$ wavelengths were higher than the blank, indicating the presence of ergosterol.

Table 1 - In vitro mycelial growth ( $\mathrm{mm}$ ) of Ganoderma applanatum, Trametes versicolor, Gloeophyllum trabeum, and Lentinus lepideus with and without cellophane membrane $(\mathrm{N}=3)$.

Tabela 1 - Crescimento micelial $(\mathrm{mm})$ in vitro de Ganoderma applanatum, Trametes versicolor, Gloeophyllum trabeum e Lentinus lepideus com e sem membrana de celofane $(N=3)$.

\begin{tabular}{|c|c|c|c|c|}
\hline $\begin{array}{l}\text { Cellophane } \\
\text { membrane }\end{array}$ & $\begin{array}{l}\text { Ganoderma } \\
\text { applanatum }\end{array}$ & $\begin{array}{c}\text { Trametes } \\
\text { versicolor }\end{array}$ & $\begin{array}{c}\text { Gloeophyllum } \\
\text { trabeum }\end{array}$ & $\begin{array}{l}\text { Lentinus } \\
\text { lepideus }\end{array}$ \\
\hline$\overline{\text { With }}$ & $52.2 \pm 2.3$ & $44.9 \pm 1.0$ & $25.3 \pm 0.6$ & $21.6 \pm 1.3$ \\
\hline Without & $54.4 \pm 2.1$ & $38.2 \pm 2.4$ & $27.3 \pm 0.8$ & $16.6 \pm 1.6$ \\
\hline
\end{tabular}




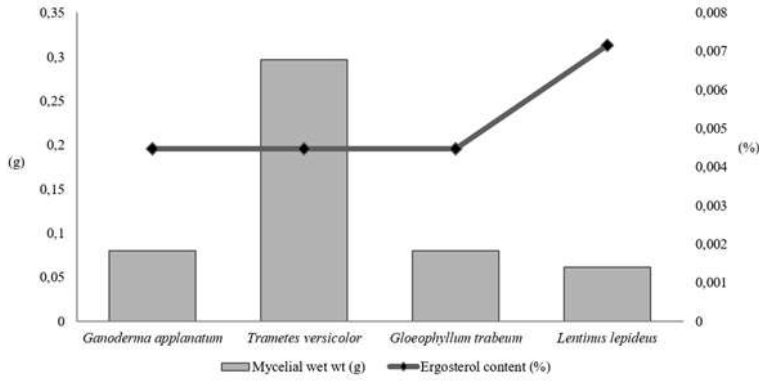

Figure 1 - Mycelial wet weight (primary axis) and ergosterol content (secondary axis) of different species of wooddecay fungi $(\mathrm{N}=3)$..

Figura 1 - Massa micelial úmida (eixo primário) e conteúdo de ergosterol (eixo secundário) de diferentes espécies de fungos apodrecedores da madeira $(N=3)$.
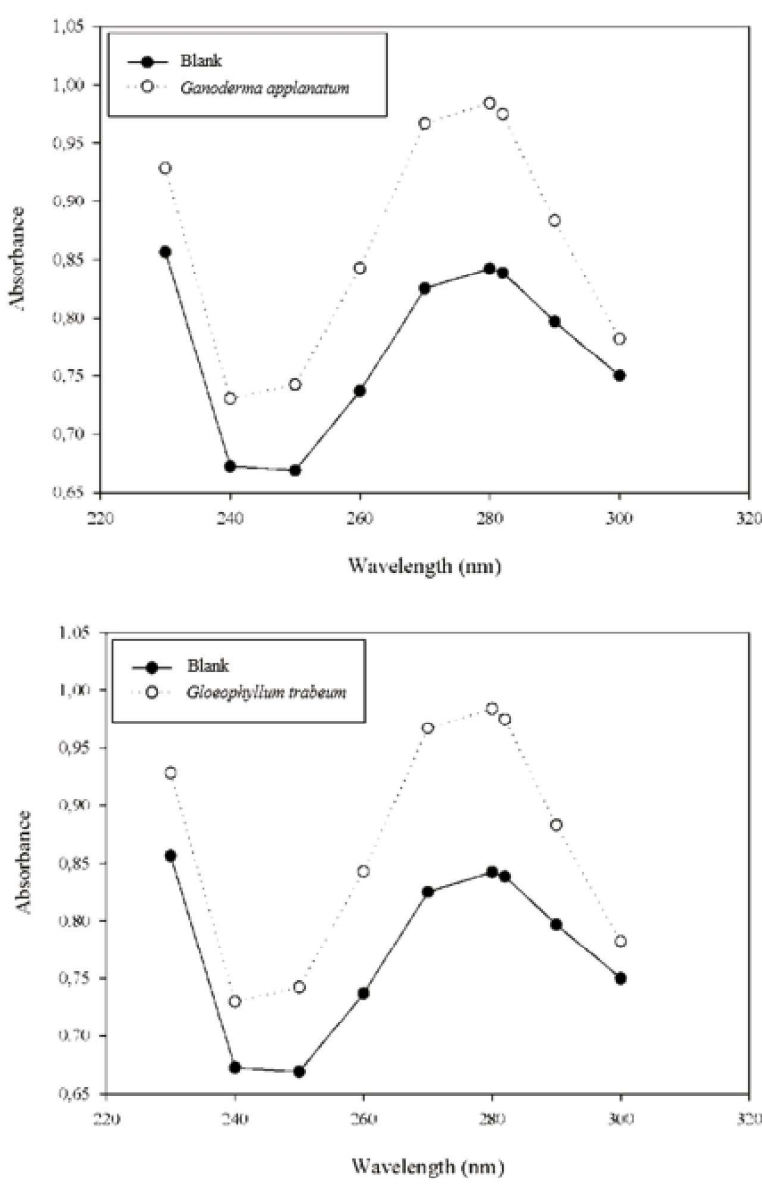

\section{DISCUSSION}

The cellophane membrane was first used to determine growth of wood-decay fungi in a study by Bento et al. (2014) in order to obtain a nutrient medium free of mycelium. The aforementioned authors determined the activity of antioxidant enzymes of filamentous fungi in the presence of plant extracts and only evaluated the white-rot species Trametes villos $a$ and Pycnoporus sanguineus. In some previously described methods, mycelia were washed in sterile distilled water after removing the culture medium (Arthington-Skaggs et al., 1999; Tian et al., 2012; Kedia et al., 2014). The use of cellophane membranes make the removal of the fungal mycelia possible without the need for washing.
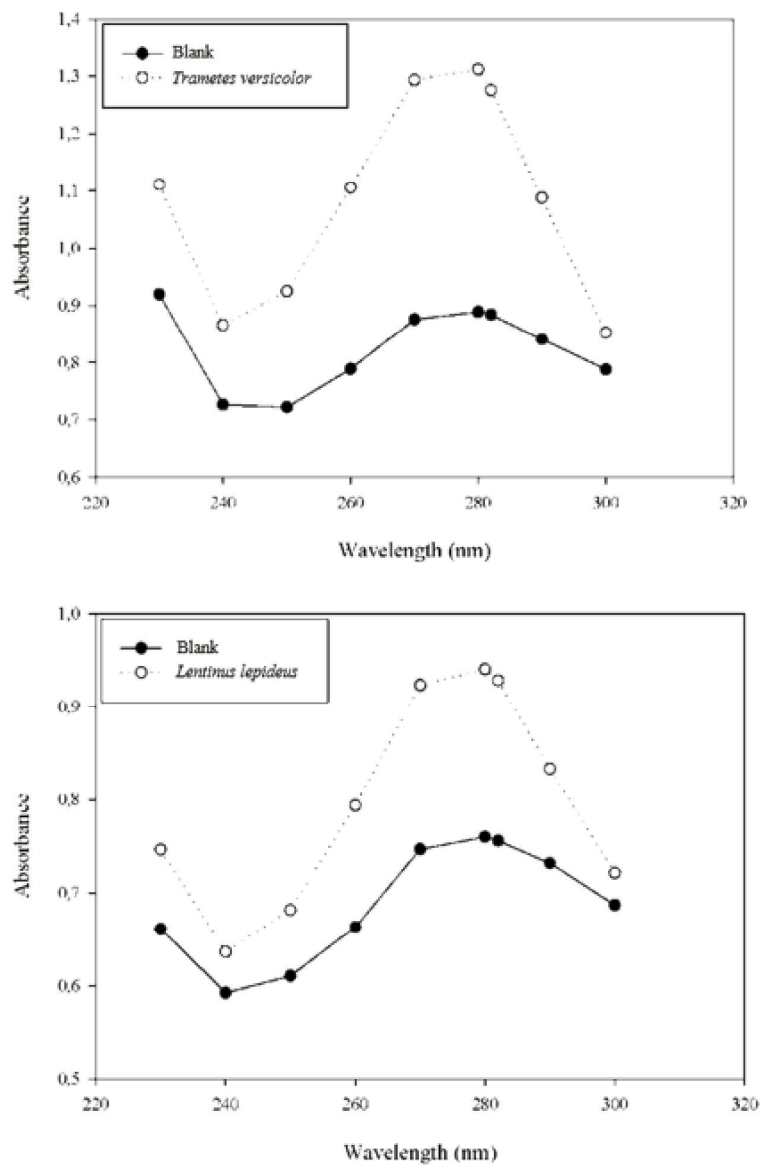

Figure 2 - UV spectrophotometric profile of ergosterol extracted from different wood-decay fungal species $(\mathrm{N}=3)$.

Figura 2 - Perfil espectrofotométrico no UV do ergosterol extraído de diferentes espécies de fungos apodrecedores da madeira ( $N=3$ ). 
This alternative prevents the washing water from influencing mycelial wet weight.

The percentages of ergosterol vary depending on the fungal species (Barajas-Aceves et al., 2002). The readings of absorbance values between 230 and 300 $\eta \mathrm{m}$ wavelengths were previously used as an indication of ergosterol presence in different studies (Breivik and Owades, 1957; Tian et al., 2012; Kedia et al., 2014). Several studies on ergosterol in wood-decay fungi are found in the literature (Gao et al., 1993; Barajas-Aceves et al., 2002; Eikenes et al., 2005; Niemenmaa et al., 2008; Chedgy et al., 2009; Song et al., 2012), although no information was reported regarding the extraction procedure used in this study. Nevertheless, a similar method was already used for extracting ergosterol from yeasts, such as Saccharomyces cerevisiae (Breivik and Owades, 1957), Candida albicans (Arthington-Skaggs et al., 1999), and the filamentous fungus Aspergillus flavus (Tian et al., 2012; Kedia et al., 2014). Since the previously described methods were not effective for ergosterol extraction of white and brown-rot fungi, the standardization of a new method was necessary.

In addition to the use of cellophane membrane, other steps were added and changes applied to the previously described methods (Tian et al., 2012; Kedia et al., 2014) in order to extract ergosterol from the selected species. After adding 25\% alcoholic potassium hydroxide to the test tubes containing mycelia, the literature recommends a vortex mix for $2 \mathrm{~min}$ (Tian et al., 2012; Kedia et al., 2014). In our method, the time of vortexing was extended to $5 \mathrm{~min}$ and a period of $5 \mathrm{~min}$ in ultrasound was added. After the addition of $2 \mathrm{ml}$ sterile distilled water and $5 \mathrm{ml} n$-heptane to the test tubes, the previous methods described a vortex mix for 2 min (Tian et al., 2012; Kedia et al., 2014). In present study, we opted to transfer the test tubes to ultrasound for $2 \mathrm{~min}$.

\section{CONCLUSION}

Our study describes a method to quantify ergosterol in the plasma membrane of wood-decay fungi. The use of cellophane membrane did not interfere in the mycelial growth of the white-rot species $G$. applanatum and $T$. versicolor, or the brown-rot species $G$. trabeum and L. lepideus. The adaptation and additional steps added to the methods already described in the literature were efficient for ergosterol extraction of wood-rot fungi and their quantitative evaluation.

\section{ACKNOWLEDGEMENTS}

This study received financial support from Conselho Nacional de Desenvolvimento Científico e Tecnológico (CNPq) [454447/2014-0 and 306449/20153] and Coordenação de Aperfeiçoamento de Pessoal de Nível Superior (CAPES). This study was financed in part by the Coordenação de Aperfeiçoamento de Pessoal de Nível Superior - Brasil (CAPES) - Finance Code 001.

\section{REFERENCES}

Arthington-Skaggs BA, Jradi H, Desai T, Morrison CJ. Quantitation of ergosterol content: novel method for determination of fluconazole susceptibility of Candida albicans. Journal of Clinical Microbiology. 1999;37(10):3332-3337.

Avanço GB, Ferreira FD, Bomfim NS, Santos PASR, Peralta RM, Brugnari T, et al. Curcuma longa L. essential oil composition, antioxidant effect, and effect on Fusarium verticillioides and fumonisin production. Food Control. 2017;73:806-813. doi: 10.1016/j. foodcont.2016.09.032

Badawy MEI, Abdelgaleil SAM. Composition and antimicrobial activity of essential oils isolated from Egyptian plants against plant pathogenic bacteria and fungi. Industrial Crops and Products. 2014;52:776-782. doi: 10.1016/j.indcrop.2013.12.003

Barajas-Aceves M, Hassan M, Tinoco R, VazquezDuhalt R. Effect of pollutants on the ergosterol content as indicator of fungal biomass. Journal of Microbiological Methods. 2002;50(3):227-236. doi: 10.1016/S0167-7012(02)00031-3

Bento TS, Torres LMB, Fialho MB, Bononi VLR. Growth inhibition and antioxidative response of wood decay fungi exposed to plant extracts of Casearia species. Letters in Applied Microbiology. 2014;58(1):79-86. doi: 10.1111/lam.12159

Brand MA, Anzaldo J, Moreschi JC. Novos produtos para o tratamento preservante da madeira. "Perspectivas da pesquisa e utilização". Floresta. 2006;36(1):129-138. doi: 10.5380/rf.v36i1.5600

Breivik ON, Owades JL. Yeast analysis, spectrophotometric semimicrodetermination of

\author{
Revista Árvore 2020;44:e4410
}


ergosterol in yeast. Journal of Agricultural and Food Chemistry. 1957;5(5):360-363. doi: 10.1021/ jf60075a005

Chedgy RJ, Lim YW, Breuil C. Effects of leaching on fungal growth and decay of western redcedar. Canadian Journal of Microbiology. 2009;55(5):578-586. doi: 10.1139/W08-161

Cheng SS, Liu JY, Chang EH, Chang ST. Antifungal activity of cinnamaldehyde and eugenol congeners against wood-rot fungi. Bioresource Technology. 2008;99(11):5145-5149. doi: 10.1016/j. biortech.2007.09.013

Eikenes M, Hietala AM, Alfredsen G, Fossdal CG, Solheim H. Comparison of quantitative real-time PCR, chitin and ergosterol assays for monitoring colonization of Trametes versicolor in birch wood. Holzforschung. 2005;59(5):568-573. doi: 10.1515/HF.2005.093

Gao Y, Chen T, Breuil C. Ergosterol - a measure of fungal growth in wood for staining and pitch control fungi. Biotechnology Techniques. 1993;7:621-626.

Hu Y, Zhang J, Kong W, Zhao G, Yang M. Mechanisms of antifungal and anti-aflatoxigenic properties of essential oil derived from turmeric (Curcuma longa L.) on Aspergillus flavus. Food Chemistry. 2017;220:1-8. doi: 10.1016/j.foodchem.2016.09.179

Kedia A, Prakash B, Mishra PK, Chanotiya CS, Dubey NK. Antifungal, antiaflatoxigenic, and insecticidal efficacy of spearmint (Mentha spicata L.) essential oil. International Biodeterioration \& Biodegradation. 2014;89:29-36. doi: 10.1016/j.ibiod.2013.10.027

Lupetti A, Danesi R, Campa M, Del Tacca M, Kelly S. Molecular basis of resistance to azole antifungals. Trends in Molecular Medicine. 2002;8(2):76-81.

Martínez ÁT, Speranza M, Ruiz-Dueñas FJ, Ferreira P, Camarero S, Guillén F, et al. Biodegradation of lignocellulosics: microbial, chemical, and enzymatic aspects of the fungal attack of lignin. International Microbiology. 2005;8(3):195-204.

Mendes RF, Bortoletto Júnior G, Garlet A, Vidal JM, Almeida NF, Jankowsky IP. Resistência de painéis compensados de Pinus taeda tratados com preservantes ao ataque de fungos xilófagos. Cerne. 2014;20(1):105112. doi: 10.1590/S0104-77602014000100014

Mota KSL, Pereira FO, Oliveira WA, Lima IO, Lima EO. Antifungal activity of Thymus vulgaris L. essential oil and its constituent phytochemicals against Rhizopus oryzae: interaction with ergosterol. Molecules. 2012;17(12):14418-14433. doi: 10.3390/ molecules 171214418

Niemenmaa O, Galkin S, Hatakka A. Ergosterol contents of some wood-rotting basidiomycete fungi grown in liquid and solid culture conditions. International Biodeterioration \& Biodegradation. 2008;62(2):125-134. doi: 10.1016/j.ibiod.2007.12.009

Oliveira JTS, Souza LC, Della Lucia RM, Souza Júnior WP. Influência dos extrativos na resistência ao apodrecimento de seis espécies de madeira. Revista Árvore. 2005;29(5):819-826. doi: 10.1590/S010067622005000500017

Presley GN, Schilling JS. Distinct growth and secretome strategies for two taxonomically divergent brown rot fungi. Applied and Environmental Microbiology. 2017;83(7):1-11. doi: 10.1128/ AEM.02987-16

Song Z, Vail A, Sadowsky MJ, Schilling JS. Competition between two wood-degrading fungi with distinct influences on residues. FEMS Microbiology Ecology. 2012;79(1):109-117. doi: 10.1111/j.15746941.2011.01201.x

Stangerlin DM, Costa AF, Garlet A, Pastore TCM. Resistência natural da madeira de três espécies amazônicas submetidas ao ataque de fungos apodrecedores. Revista Ciência da Madeira (Brazilian Journal of Wood Science). 2013;4(1):15-32. doi: 10.12953/2177-6830.v04n01a02

Tian J, Huang B, Luo X, Zeng H, Ban X, He $\mathrm{J}$, et al. The control of Aspergillus flavus with Cinnamomum jensenianum Hand.-Mazz essential oil and its potential use as a food preservative. Food Chemistry. 2012;130(3):520-527. doi: 10.1016/j. foodchem.2011.07.061

Vivian MA, Santini EJ, Modes KS, Garlet A, Morais WWC. Resistência biológica da madeira tratada 
de Eucalyptus grandis e Eucalyptus cloeziana a fungos apodrecedores em ensaios de laboratório. Ciência Florestal. 2015;25(1):175-183. doi: $10.5902 / 1980509817475$
Xie Y, Wang Z, Huang Q, Zhang D. Antifungal activity of several essential oils and major components against wood-rot fungi. Industrial Crops and Products. 2017;108:278-285. doi: 10.1016/j.indcrop.2017.06.041 